\title{
COMPARATIVE ANALYSIS OF HEDONIC AND FILTERED INDEXES IN SELECTED CITIES
}

\author{
Sebastian Kokot, prof. \\ Faculty of Economics and Management \\ University of Szczecin \\ e-mail: sebastian.kokot@wneiz.pl
}

\begin{abstract}
Property price indexes are difficult to determine both from the substantive and technical/organizational points of view. Various methods of constructing such indexes have been developed in order to overcome these difficulties. To this end, the author compares two types of indexes: hedonic indexes and ones termed filtered for the purpose of this particular paper. Hedonic index values come from Polish National Bank (NBP) publications, while the filtered indexes have been computed with the use of the $4253 \mathrm{H}$ filter on the basis of the NBP announcements on mean property prices. Thus, the results are comparable as both types of indexes are derived from the same input databases. The analysis covers both the comparison of the obtained results as well as a discussion of substantive and technical problems encountered when building the property price indexes.
\end{abstract}

Key words: real estate market, indices, property prices.

\section{JEL Classification: $R 20$.}

Citation: Kokot S., 2017, Comparative Analysis of Hedonic and Filtered Indexes in Selected Cities, Real Estate Management and Valuation, vol. 25, no. 3, pp. 40-50.

DOI: 10.1515/remav-2017-0021

\section{Introduction}

It took almost two decades of market economy in Poland before the Polish real estate market finally understood the need for property price indices and learned how to determine them. The obligation to use such indices in specified situations to calculate price updates, value, fees, compensation payments or salaries was introduced by the Property Management Act of 1998. The Act imposes the obligation to announce "indices of changes in property prices broken into specific property types in individual voivodships" on the President of the Central Statistical Office. The publishing of residential property prices started no sooner than in the $2^{\text {nd }}$ quarter of 2015, i.e. almost 18 years after the legal regulations had entered into force. Since 2010, reports about the Polish real estate market have been published by the National Bank of Poland on a quarterly basis. The reports are supplemented with a database of residential property prices, including mean unit prices in selected cities and in groups of cities, as well as thus determined prices of a square meter. This database has been completed with information going back to 2006. Simultaneously, the studies on improving the methods for property price determination are conducted more or less regularly. The works are of great interest as property price indices are difficult to compute both from a substantive and technical/organizational point of view. The substantive problems are associated with the specific character of the real estate market as well as of the marketed properties themselves (see, e.g.: Wycena nieruchomości 2006). Due to this unique nature, property price indices cannot be constructed by means of methods applied for creating price indices of other marketed goods (Wood 2005), because real estate prices are observed in a nonstandard way (КОКОТ 2015b). The number of transactions on the real estate market is relatively small and every transaction differs substantially from other ones. Consequently, in each subsequent period 
of time, the marketed properties form groups of different qualitative structure. When constructing property price indices, researchers find the issue of heterogeneity of marketed objects in various periods of time to be of key importance (GUO, ZHENG, et al. 2014). The technical/organizational problems result mainly from the difficulty in gaining access to reliable and possibly the most homogeneous data about transactions. In practice, the process of collecting such information means tedious, time-consuming and often remunerated looking through notary acts in search of key data. What is more, the quality of the data often leaves a lot to be desired (Konowalczuk 2014, Kokot $2015 a$ ).

\section{Literature review - methods for determining property price indices}

The methods for determining property price indices fall into three main groups. The actual transaction prices should be the source of data needed to compute these indices, but these are sometimes based on offer prices (see e.g.: КОКОт 2014, Trojanek 2009, Trojanek 2010). In the first group of methods, the value which corresponds to an adequately defined mean of prices recorded on the market in a given period of time is calculated, and is then related to the mean price in the preceding period of time. No attention is paid to aspects connected with the sample's heterogeneity. In more advanced forms of this method, the indices are determined for more homogeneous groups of properties, due to which the samples are more homogeneous, but smaller. Another modification of this method is based on using time series of mean prices that are smoothed by means of adequate statistical procedures (see e.g.: КОКОт 2016А, КОКОт 2016в). The main advantage of this method is the simplicity of computations, while its weak point are samples that are diversified in terms of their qualitative structure, from which the mean prices are derived in individual time periods. The second group consists of the repeat-sales methods. Generally, these consist in calculating indices for properties that have been marketed at least twice in a given period of time and in averaging the results for a given market. What is a drawback of these methods are the changes to the properties occurring between transactions, which affects their market price. This effect is amplified by the fact that some properties are purchased with an intention to upgrade and re-sale with profit. The third group of methods include hedonic, or econometric, models, where the price is the dependent variable while the independent variables are the characteristics of a heterogenic good (TOMCZYK, WIDŁAK 2010). These models are used for periodic property valuation and for surveying price changes on markets of heterogeneous goods (including real estate) as they allow for taking into account changes in the quality of these goods (WIDŁAK 2010). The advantage of these methods is the possibility to include in the considerations the effect of specific attributes of a property on its value. Their elementary disadvantage is the need to gather and constantly update plenty of data necessary to build the model and valuate the property (NICHOLAS, SCHERBINA 2013). Unfortunately, even these indices cannot embrace all the property characteristics that determine its price (HILL 2011), thus it is hard to construct good and very good models of the property value (obtained $\mathrm{R}^{2}$ rarely reach the level of 0.8 , often being much lower, see: CEGIELSKI 2013). The above-mentioned methods are sometimes used in their variations or in hybrid forms (TROJANEK 2008).

There are numerous studies comparing the values of property price indices obtained in various ways, also the ones dealing with the Polish property market. They have revealed that, between 1997 and 2008, the indices computed on the basis of arithmetic means of offer prices in Poznan reflected the movements of market prices only slightly less accurately than the indices determined basing on weighted means (TROJANEK 2009). On the other hand, the comparison of indices based on arithmetic means or medians with hedonic indices can bring different results (TROJANEK 2010).

\section{Data and Methods}

Further in the article, a comparative analysis is made of two types of quarterly indices of residential property prices. The first type comprises hedonic indices computed and published by NBP. The database of residential property prices, on which these indices are based on, consists of information reported on a voluntary basis by real estate agents and developers to regional divisions of NBP. In the present study, the author makes use of the available, published indices. NBP does not provide information about the applied method; it merely indicates that the hedonic index of residential property prices includes the correction on differences in attributes (such as location, useful floor area, F\&F standard) of properties sold in specific periods of time, and that the hedonic index is computed by means of the imputation method (a reference is made to (WIDŁAK 2010)). 
For the purpose of this article the second type of indices has been termed "filtered". They have been computed using the $4253 \mathrm{H}$ filter on the basis of data on mean prices published by NBP, i.e. the same data which are used by NBP to determine its hedonic indices. Hence, the study results are comparable because both types of indices are, as a matter of fact, derivatives of the same sets of input data. For the same reason, the analyzed cities are the ones for which NBP has published the mean residential property prices and determined their indices. The $4253 \mathrm{H}$ filter (VELLEMAN 1980) is applied in many scientific fields, not only in economics where the observed process must be cleared of so-called random errors. This tool ensures very good behavior of the original process while smoothing random oscillations (GAMRACKI, GAMRACKI 2009). The validity and benefits of using this filter to smooth time series of mean prices for the purpose of calculating property rice indices have already been discussed in (КОКОТ 2016, КОКОТ 2017). The filter consists of the following transformations of the time series:

1. smoothing the series by a moving median of 4 centered by a running median of 2 ,

2. smoothing the series obtained in step (1) by a running median of 5 ,

3. smoothing the series obtained in step (2) by a running median of 4 ,

4. smoothing the series obtained in step (3) by a 3-point weighted moving average with Hanning weights $(0.25,0.5,0.25)$,

5. computing residuals by subtracting the smoothed series from the original series,

6. repeating steps $1-4$ on the residuals,

7. adding the transformed residuals to the smoothed series.

The study was conducted on the basis of the NBP data on mean prices in the $3^{\text {rd }}$ quarter of 2006 $(\mathrm{t}=1)$ to the $2^{\text {nd }}$ quarter of $2016(\mathrm{t}=\mathrm{n}=40)$ in Białystok, Bydgoszcz, Trójmiasto, Katowice, Kielce, Kraków, Lublin, Łódź, Olsztyn, Opole, Poznań, Rzeszów, Szczecin, Warszawa, Wrocław and Zielona Góra. The selection of cities was determined by the system applied by NBP. NBP provided average prices for Gdańsk and Gdynia (being parts of the metropolitan area of Trójmiasto), while the relevant index was published for Trójmiasto as a whole, which resulted in a certain inaccuracy in further computations. The filtered index for Trójmiasto was determined on the basis of prices in Gdańsk because the mean prices in Trójmiasto were not available.

The filtered indices were computed basing on the values of mean price series smoothed by this filter:

$$
i_{t}^{F}=\frac{X_{t}}{X_{t-1}} \times 100
$$

where:

$X_{t} \quad$ - the unit price from the series smoothed with the filter in the quarter for which the index is being computed,

$\mathrm{X}_{\mathrm{t}-1}$ - the unit price from the series smoothed with the filter in the quarter preceding the one for which the index is being computed,

Thus, they are the quarterly chain indices, just like the hedonic indices used for comparison (NBP also publishes annual indices computed on a quarterly basis). One ought to note that the "first index" was computed for $\mathrm{t}=2$, which means that the indices were determined for 39 quarters.

Moreover, to make the comparison more precise, the following values were computed:

The index of price change in time $\mathrm{T}$ basing on the hedonic indices:

$$
I_{T}^{H}=\prod_{t=5}^{t=n-3}\left(i_{t}^{H} / 100\right) \times 100
$$

The index of price change in time $\mathrm{T}$ basing on the filtered indices:

$$
I_{T}^{F}=\prod_{t=5}^{t=n-3}\left(i_{t}^{F} / 100\right) \times 100
$$

The index of price change in time $\mathrm{T}$ basing on the mean prices published by NBP:

$$
I_{T}^{C}=\frac{C_{n-3}}{C_{4}} \times 100
$$

The mean rate of price changes in time $\mathrm{T}$ basing on the hedonic indices: 


$$
\bar{I}_{T}^{H}=\sqrt[n-7]{\prod_{t=5}^{t=n-3}\left(i_{t}^{H} / 100\right)} \times 100
$$

The mean rate of price changes in time $\mathrm{T}$ basing on the filtered indices:

$$
\bar{I}_{T}^{F}=\sqrt[n-7]{\prod_{t=5}^{t=n-3}\left(i_{t}^{F} / 100\right)} \times 100
$$

The mean rate of price changes in time $\mathrm{T}$ basing on the mean prices published by NBP:

$$
\bar{I}_{T}^{C}=\sqrt[n-7]{\frac{C_{n-3}}{C_{4}}} \times 100
$$

The standard deviation of the hedonic chain indices:

$$
s^{H}=\sqrt{\frac{\sum_{t=5}^{t=n-3}\left[\left(i_{t}^{H}-100\right)-\left(\overline{i_{t}^{H}-100}\right)\right]^{2}}{(n-7-1)}}
$$

The standard deviation of the filtered chain indices:

$$
s^{F}=\sqrt{\frac{\sum_{t=5}^{t=n-3}\left[\left(i_{t}^{F}-100\right)-\left(\overline{i_{t}^{F}-100}\right)\right]^{2}}{(n-7-1)}}
$$

All the computations were made separately for each city. As seen above, the time T was the period of time shortened by the initial three and final three quarters for which the chain indices were computed, thus the time $T$ includes the period between the $3^{\text {rd }}$ quarter of 2007 and the $3^{\text {rd }}$ quarter of 2015 (from $t=5$ to $t=n-3$ ). Such a decision was made owing to the possible distortion of the extreme values of the filtered chain indices, which results directly from the adopted filtering procedure. In the case of the remaining types of indices, the shortening was made in order to ensure the comparability of results.

\section{Empirical results}

The obtained results, i.e. the values of the filtered indices and the NBP hedonic indices for individual cities, are shown in Figures 1-16.

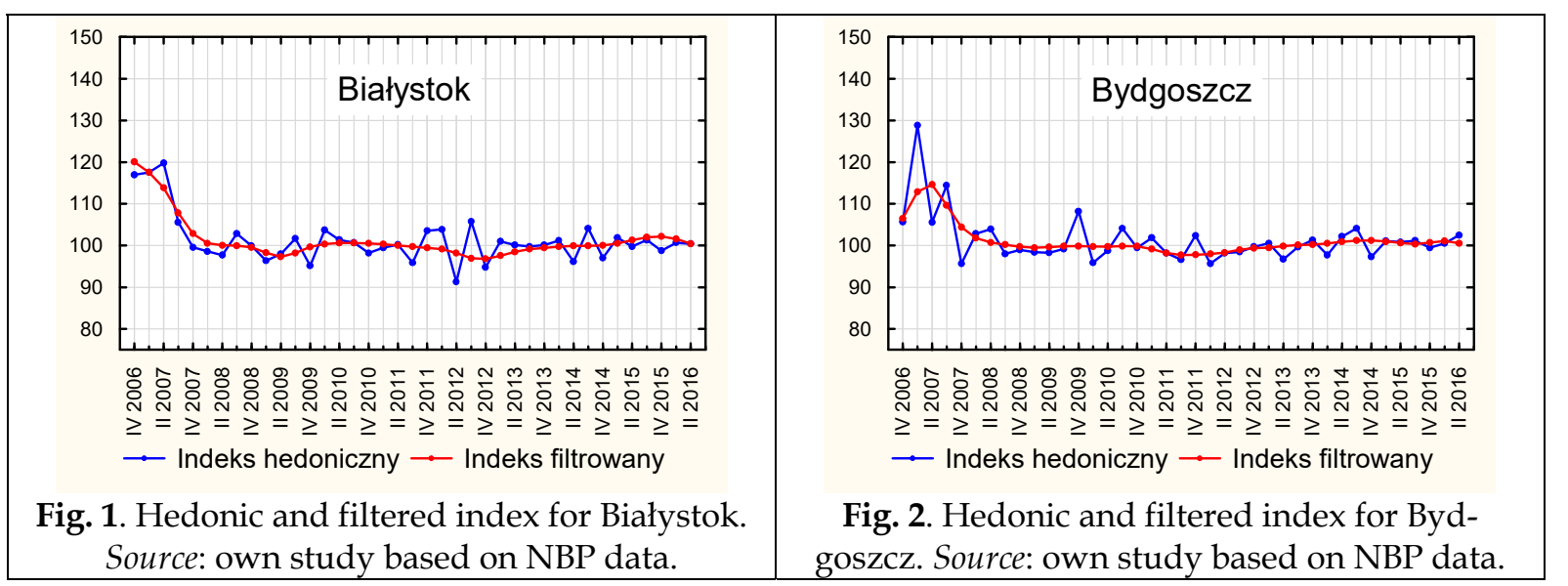




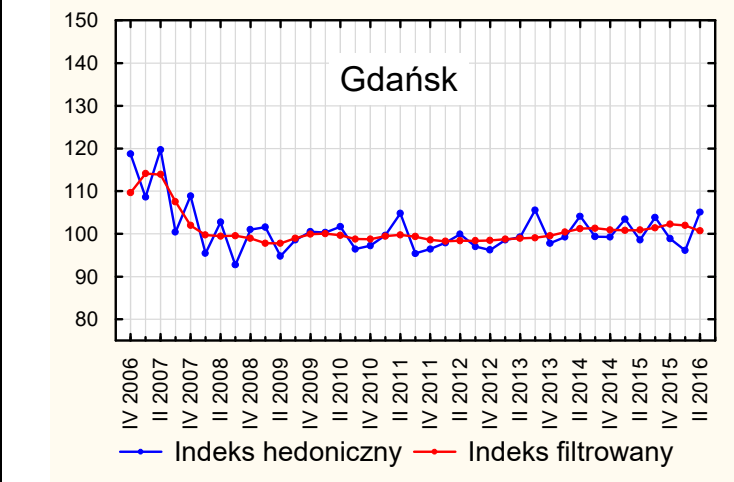

Fig.3. Hedonic and filtered index for Gdańsk. Source: own study based on NBP data.

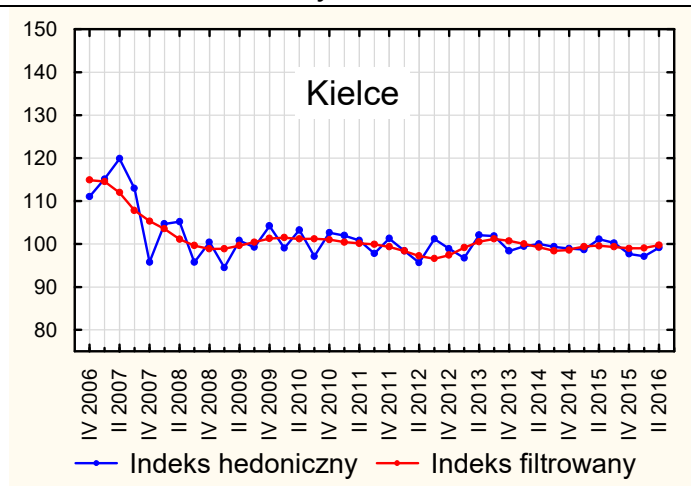

Fig. 5. Hedonic and filtered index for Kielce. Source: own study based on NBP data.

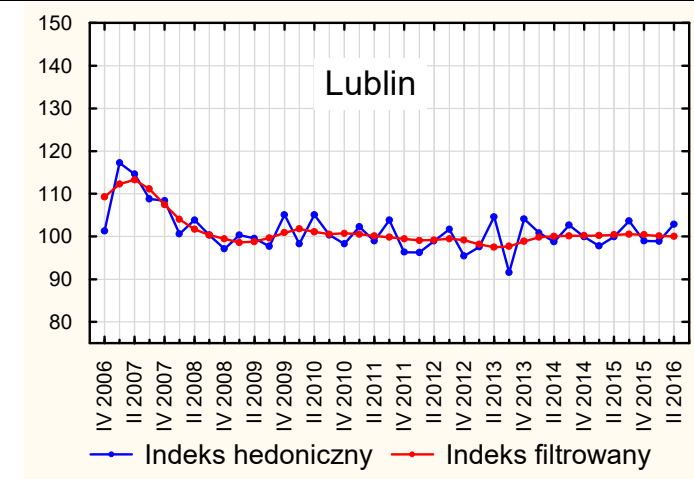

Fig. 7. Hedonic and filtered index for Lublin. Source: own study based on NBP data.

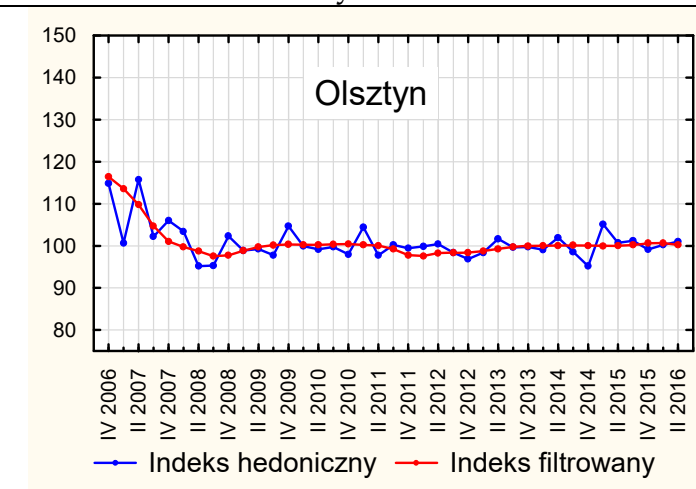

Fig. 9. Hedonic and filtered index for Olsztyn. Source: own study based on NBP data.

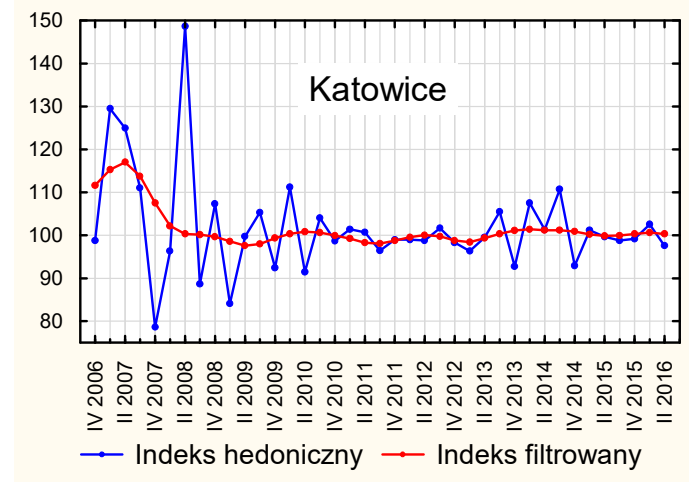

Fig. 4. Hedonic and filtered index for Katowice. Source: own study based on NBP data.
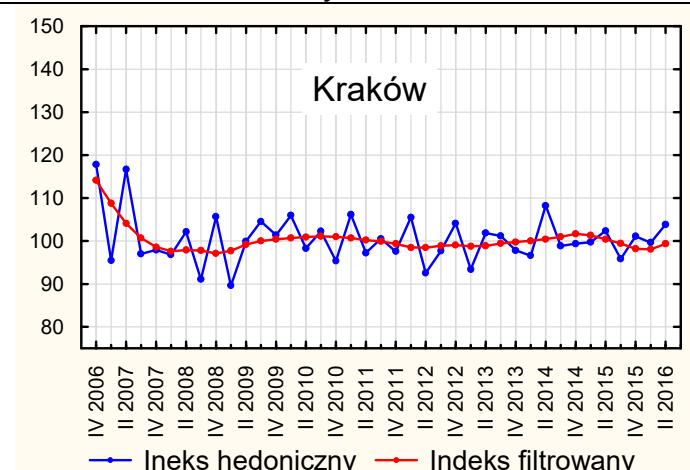

$\longrightarrow$ Ineks hedoniczny $\longrightarrow$ Indeks filtrowany

Fig. 6. Hedonic and filtered index for Krakow. Source: own study based on NBP data.

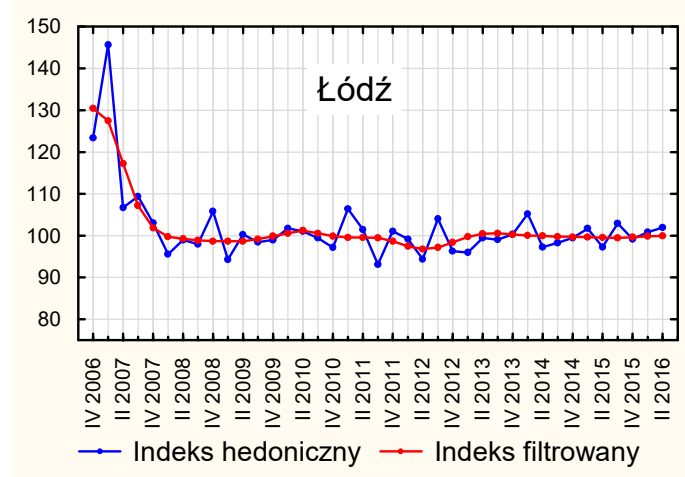

Fig. 8. Hedonic and filtered index for Łódź. Source: own study based on NBP data.

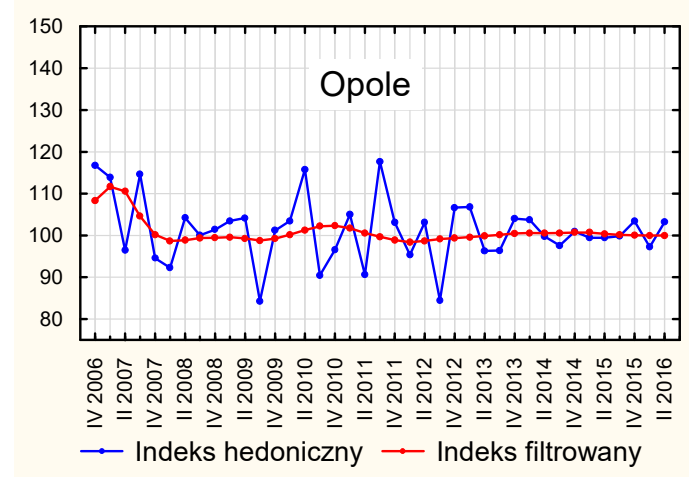

Fig. 10. Hedonic and filtered index for Opole. Source: own study based on NBP data. 


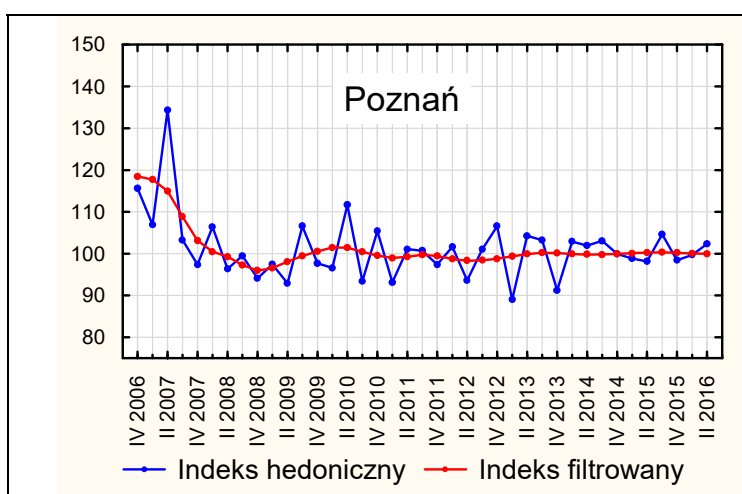

Fig. 11. Hedonic and filtered index for Poznań. Source: own study based on NBP data.

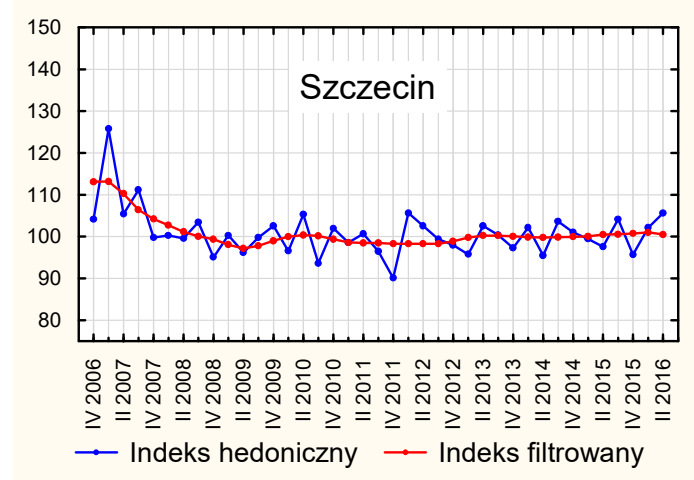

Fig. 13. Hedonic and filtered index for Szczecin. Source: own study based on NBP data.

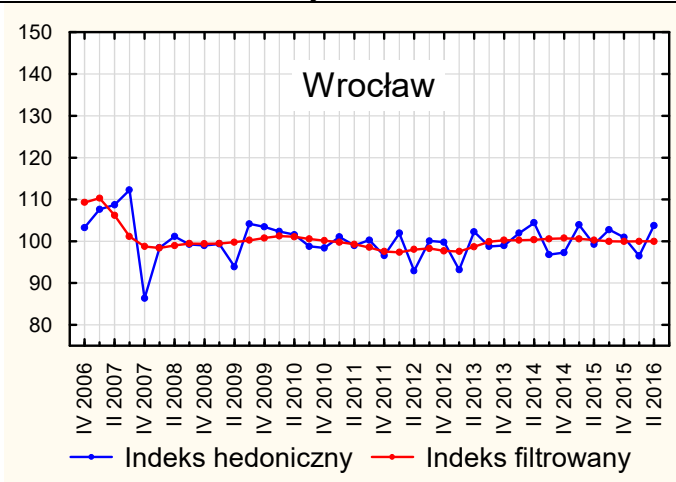

Fig. 15. Hedonic and filtered index for Wroclaw. Source: own study based on NBP data.

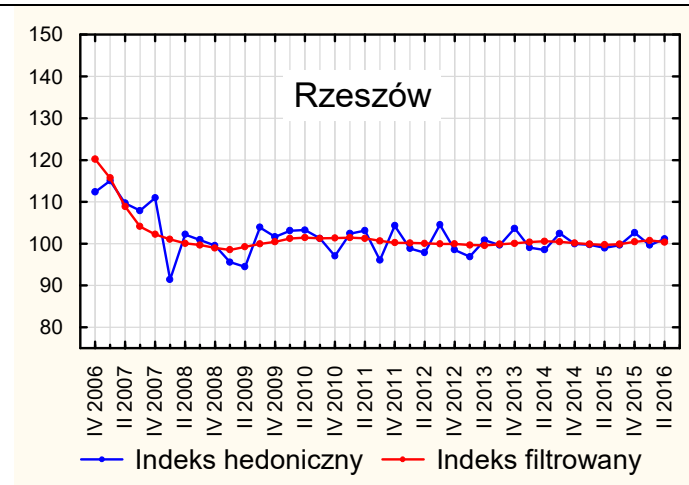

Fig. 12. Hedonic and filtered index for Rzeszow. Source: own study based on NBP data.

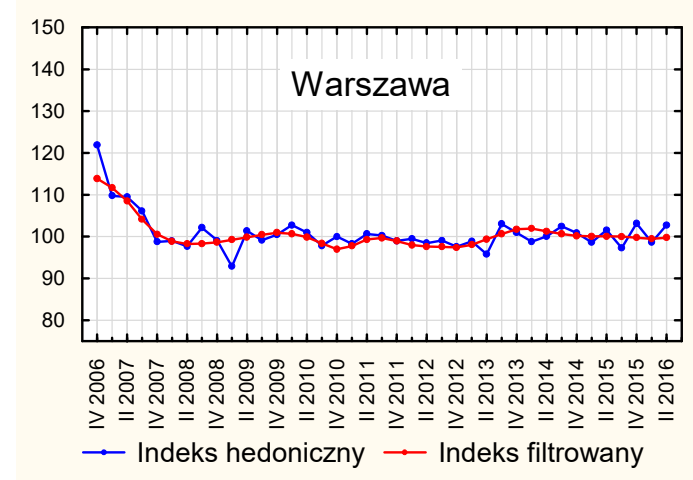

Fig. 14. Hedonic and filtered index for Warsaw. Source: own study based on NBP data.

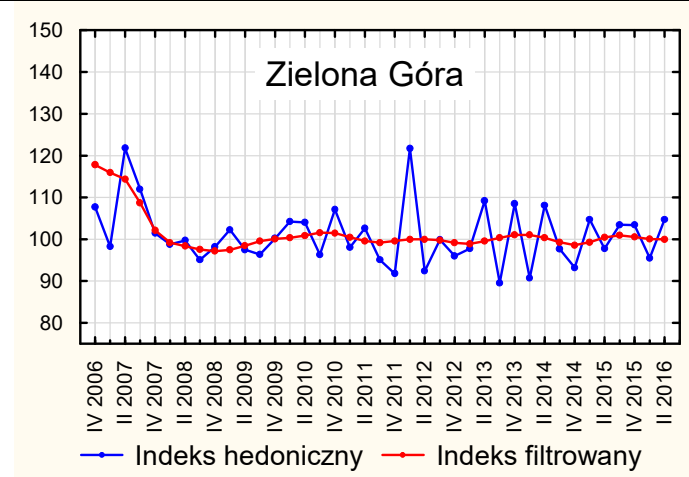

Fig. 16. Hedonic and filtered index for Zielona Góra. Source: own study based on NBP data.

It can be clearly seen that the series of filtered indices were smoother, less vulnerable to short-term fluctuation or surges. In extreme cases, the hedonic index values jumped by as much as $50 \%$ (Łódź, Katowice) in comparison to the previous quarter. Changes of $20 \%$ were seen quite frequently. What may confirm that these indices are unrealistic is the fact that, in subsequent quarters, there were dramatic changes in the opposite direction, or at least a reduction to levels corresponding to relatively small price changes. It should be noted that the period of study also encompasses the boom on the real estate market (2006-2008), i.e. the time of sudden and substantial real price movements. It does not facilitate the observation of price changes; on the contrary, it puts the research methods to test. Nevertheless, even in the period of relative price stability (after 2008), it seems hard to believe in a situation like the one observed in Zielona Góra where the hedonic index shows that, in the 4th quarter of 2011 , the prices fell by an average of $8.2 \%$ in relation to the preceding quarter, only to rise by $21.7 \%$ in the $1^{\text {st }}$ quarter of 2012 and drop again by $7.6 \%$ in the subsequent quarter. By comparison, the filtered index computed for Zielona Góra indicated a $0.4 \%$ decline in average prices in the 4th quarter of 2011, and no price movements whatsoever in the following two quarters. It is worth emphasizing 
that both indices were determined basing on exactly the same input data! In this context, the filtered indices are much more reliable as they indicate stable trends rather than sudden and short-term price surges. Theoretically, this is what the real estate market is characterized by - low demand and supply flexibility, limited resources and long-lasting investment processes, as well as relatively long procedures leading to a transaction. All this means that sudden and short-lived leaps of prices are rather unnatural for this market.

The difficulty in deciding whether a given method of computing property price indices lies in the fact there is nothing to relate to the obtained, because these methods, in a sense, serve to measure the phenomenon (of price movements on the real estate market). We can compare the role of the method to a thermometer. However, when measuring temperature, we refer to certain control points, such as the boiling or the freezing point. When "measuring" mean price movements on the property market, we do not have such control points "hooked" in the reality. All we can do is to compare the results obtained by means of different methods and refer them to various theories. Hence, the above comparative analysis of two methods of determining property price indices seems to lead to a definitive conclusion that filtered indices work better than hedonic ones. Additionally, it should be noted that ${ }_{L}$ besides their better informative value, the filtered indices have a technical/organizational advantage over the hedonic indices. In the case of the filtered indices it is sufficient to have the database of transaction prices or even just mean prices on local real estate markets (e.g. in individual cities) in specific periods of time. Minor errors or oversights in such databases have no considerable impact on the quality of results. There is no need to collect details on the attributes of individual marketed properties because, by filtering the series of mean prices, these attributes are averaged automatically. In a sense, the filtered mean prices provide information about the "mean price of the average property" being the property whose attributes were the resultant of the properties traded in a particular period of time and, to some extent, in the neighboring periods. Also, the computing procedure is relatively uncomplicated. The results are comparable both in time (in different periods) and in space (e.g. in various cities) since they are obtained with the use of an identical computing procedure. Hedonic indices do not have such advantages as they require gathering detailed data about the marketed property attributes. It should also be noted that these attributes are often selfperceived (an attribute which is important for one person may be found irrelevant by another person). Moreover, on different local markets the property prices can be determined by various property attributes. In some methods for computing hedonic indices it is necessary to build the so called representative basket of properties. This basket also varies depending on the time and location. The procedures of building economic models on which the values serving index computation are based are complicated and their every stage carries the risk of generating errors that will affect the ultimate results. The necessity to build a new property basket for each period of time and each local market results in poor comparability of results.

To supplement the findings concerning the values of the indices themselves, Table 1 outlines the selected measures serving their parametric comparison:

- the index of price changes in the time T based on the hedonic indices $I_{T}^{H}$ computed following Formula (2),

- the index of price changes in the time $\mathrm{T}$ based on the filtered indices $I_{T}^{F}$ computed following Formula (3),

- the index of price changes in the time T based on mean prices published by NBP $I_{T}^{C}$ computed following Formula (4),

- the average rate of price changes in the time T based on the hedonic indices $\bar{I}_{T}^{H}$ computed following Formula (5),

- the average rate of price changes in the time $\mathrm{T}$ based on the filtered indices $\bar{I}_{T}^{F}$ computed following Formula (6),

- the average rate of price changes in the time T based on mean prices published by NBP $\bar{I}_{T}^{C}$ computed following Formula (7),

- the standard deviation of the hedonic chain indices $s^{H}$ computed following Formula (8),

- the standard deviation of the filtered chain indices $s^{F}$ computed following Formula (9), 
- the difference between the price change index in the time T computed on the basis of the mean prices published by NBP and the price change index in the time T computed on the basis of the hedonic indices, and marked in Table 1 as "difference $I$ 1",

- the difference between the price change index in time T computed on the basis of mean prices published by NBP and the price change index in the time T computed on the basis of the filtered indices and marked in Table 1 as "difference $I$ 2",

- the difference between the price change index in the time $\mathrm{T}$ computed on the basis of the filtered indices and the price change index in the time T computed on the basis of the hedonic indices and marked in Table 1 as "difference $I$ 3",

- the difference between the average rate of price changes in the time $\mathrm{T}$ based on the mean prices published by NBP and the average rate of price changes in the time T computed on the basis of the hedonic indices and marked in Table 1 as "difference $\bar{I}{ }_{1}$ ",

- the difference between the average rate of price changes in the time $\mathrm{T}$ based on the mean prices published by NBP and the average rate of price changes in the time T computed on the basis of the filtered indices and marked in Table 1 as "difference $\bar{I}$ ",

- the difference between the average rate of price changes in the time $\mathrm{T}$ based on the filtered indices and the average rate of price changes in the time $\mathrm{T}$ based on hedonic indices and marked in Table 1 as "difference $\bar{I} 3^{\prime \prime}$.

As seen above, for the purpose of comparison, such measures as the price change index and the average rate of price changes in the time $\mathrm{T}$ were also determined basing directly on the mean prices published by NBP.

Selected measures serving parametric comparison of hedonic and filtered indices

Table 1

\begin{tabular}{ccccc}
\hline Measure & Białystok & Bydgoszcz & Trójmiasto & Katowice \\
\hline$I_{T}^{H}$ & 0.9506 & 1.0774 & 0.8775 & 1.0100 \\
\hline$I_{T}^{F}$ & 0.9435 & 1.0685 & 0.9300 & 1.1493 \\
\hline$I_{T}^{C}$ & 0.9621 & 1.0435 & 0.8808 & 0.8531 \\
\hline $\bar{I}_{T}^{H}$ & 0.9984 & 1.0023 & 0.9959 & 1.0003 \\
\hline $\bar{I}_{T}^{F}$ & 0.9982 & 1.0021 & 0.9977 & 1.0044 \\
\hline $\bar{I}_{T}^{C}$ & 0.9988 & 1.0013 & 0.9960 & 0.9950 \\
\hline$s^{H}$ & 0.0326 & 0.0380 & 0.0346 & 0.1123 \\
\hline$s^{F}$ & 0.0196 & 0.0211 & 0.0176 & 0.0295 \\
\hline difference $I_{1}$ & 0.0115 & -0.0338 & 0.0034 & -0.1569 \\
\hline difference $I_{2}$ & 0.0185 & -0.0250 & -0.0492 & -0.2962 \\
\hline difference $I_{3}$ & -0.0070 & -0.0088 & 0.0525 & 0.1393 \\
\hline difference $\bar{I}_{1}$ & 0.0004 & -0.0010 & 0.0001 & -0.0053 \\
\hline difference $\bar{I}_{2}$ & 0.0006 & -0.0007 & -0.0017 & -0.0093 \\
\hline difference $\bar{I}_{3}$ & -0.0002 & -0.0003 & 0.0018 & 0.0040 \\
\hline & Kielce & Kraków & Lublin & Łódź \\
\hline$I_{T}^{H}$ & 1.0667 & 0.8272 & 1.1766 & 0.9335 \\
\hline$I_{T}^{F}$ & 1.0623 & 0.8731 & 1.1673 & 0.9055 \\
\hline$I_{T}^{C}$ & 1.1398 & 1.0065 & 0.8339 & 1.1716 \\
\hline $\bar{I}_{T}^{H}$ & 1.0020 & 0.9941 & 1.0051 & 0.9979 \\
\hline & & & & \\
\hline & & & & \\
\hline & & & & \\
\hline
\end{tabular}




\begin{tabular}{|c|c|c|c|c|}
\hline $\bar{I}_{T}^{F}$ & 1.0019 & 0.9958 & 1.0048 & 0.9969 \\
\hline $\bar{I}_{T}^{C}$ & 1.0041 & 1.0002 & 0.9943 & 1.0050 \\
\hline$s^{H}$ & 0.0348 & 0.0449 & 0.0371 & 0.0367 \\
\hline$s^{F}$ & 0.0218 & 0.0121 & 0.0262 & 0.0172 \\
\hline difference $I_{1}$ & 0.0731 & 0.1793 & -0.3427 & 0.2381 \\
\hline difference $I_{2}$ & 0.0775 & 0.1334 & -0.3334 & 0.2661 \\
\hline difference $I_{3}$ & -0.0044 & 0.0459 & -0.0094 & -0.0280 \\
\hline difference $\bar{I}_{1}$ & 0.0021 & 0.0061 & -0.0108 & 0.0071 \\
\hline difference $\bar{I}_{2}$ & 0.0022 & 0.0044 & -0.0105 & 0.0081 \\
\hline \multirow[t]{2}{*}{ difference $\bar{I}_{3}$} & -0.0001 & 0.0017 & -0.0003 & -0.0009 \\
\hline & Olsztyn & Opole & Poznań & Rzeszów \\
\hline$I_{T}^{H}$ & 0.9952 & 1.0840 & 0.8796 & 1.1732 \\
\hline$I_{T}^{F}$ & 0.8898 & 1.0412 & 0.9406 & 1.1448 \\
\hline$I_{T}^{C}$ & 0.9005 & 0.8634 & 1.0472 & 0.9207 \\
\hline $\bar{I}_{T}^{H}$ & 0.9999 & 1.0025 & 0.9960 & 1.0050 \\
\hline $\bar{I}_{T}^{F}$ & 0.9964 & 1.0013 & 0.9981 & 1.0042 \\
\hline $\bar{I}_{T}^{C}$ & 0.9967 & 0.9954 & 1.0014 & 0.9974 \\
\hline$s^{H}$ & 0.0273 & 0.0754 & 0.0515 & 0.0380 \\
\hline$s^{F}$ & 0.0132 & 0.0127 & 0.0212 & 0.0103 \\
\hline difference $I_{1}$ & -0.0947 & -0.2206 & 0.1676 & -0.2525 \\
\hline difference $I_{2}$ & 0.0107 & -0.1778 & 0.1066 & -0.2241 \\
\hline difference $I_{3}$ & -0.1055 & -0.0428 & 0.0609 & -0.0284 \\
\hline difference $\bar{I}_{1}$ & -0.0031 & -0.0071 & 0.0054 & -0.0076 \\
\hline difference $\bar{I}_{2}$ & 0.0004 & -0.0058 & 0.0034 & -0.0068 \\
\hline \multirow[t]{2}{*}{ difference $\bar{I}_{3}$} & -0.0035 & -0.0013 & 0.0021 & -0.0008 \\
\hline & Szczecin & Warszawa & Wrocław & Zielona Góra \\
\hline$I_{T}^{H}$ & 0.9391 & 0.8880 & 0.8723 & 1.0460 \\
\hline$I_{T}^{F}$ & 0.9383 & 0.8577 & 0.8595 & 1.0002 \\
\hline$I_{T}^{C}$ & 1.1320 & 0.9533 & 0.8564 & 0.8465 \\
\hline $\bar{I}_{T}^{H}$ & 0.9980 & 0.9963 & 0.9957 & 1.0014 \\
\hline $\bar{I}_{T}^{F}$ & 0.9980 & 0.9952 & 0.9953 & 1.0000 \\
\hline $\bar{I}_{T}^{C}$ & 1.0039 & 0.9985 & 0.9952 & 0.9948 \\
\hline$s^{H}$ & 0.0402 & 0.0236 & 0.0434 & 0.0675 \\
\hline$s^{F}$ & 0.0182 & 0.0154 & 0.0114 & 0.0196 \\
\hline difference $I_{1}$ & 0.1929 & 0.0654 & -0.0159 & -0.1994 \\
\hline difference $I 2$ & 0.1937 & 0.0956 & -0.0031 & -0.1536 \\
\hline difference $I 3$ & -0.0008 & -0.0303 & -0.0128 & -0.0458 \\
\hline difference $\bar{I}_{1}$ & 0.0058 & 0.0022 & -0.0006 & -0.0066 \\
\hline difference $\bar{I}_{2}$ & 0.0059 & 0.0033 & -0.0001 & -0.0052 \\
\hline
\end{tabular}




\begin{tabular}{ccccc}
\hline difference $\bar{I}_{3}$ & 0.0000 & -0.0011 & -0.0005 & -0.0014 \\
\hline
\end{tabular}

Source: Own study.

When analyzing the above-listed comparative parameters, it can be concluded that the discrepancies between the average rate of price changes throughout the analysis period determined for all the cities on the basis of the hedonic and the filtered indices are very small as they are expressed to three or four decimal places, which is less than $1 \%$ over the entire 8-year period. Slightly bigger differences between this average rate of price changes and the average price change rate based directly on the mean prices can be explained by higher randomness of these prices in the initial and final quarters. Much more considerable differences appear when we compare the price changes in the analysis period. Here, the differences are expressed to the second, or even first decimal place, which indicates that the changes in prices determined with different types of indices can vary by more than $10 \%$. Such a discrepancy should be considered substantial, thus confirming the fact that at least one of the indices being compared is defective. What also seems noteworthy is the comparison of the standard deviation of hedonic and filtered indices. The former are always bigger, occasionally several times bigger. Hence, it seems that if we relied solely on hedonic indexes, we would come to a conclusion that property prices change more often and more dramatically than if we based our computations on filtered indices.

\section{Conclusions}

The above presented studies prove that, apart from its simplicity and the absence of the requirement to collect details regarding each transaction, the proposed method for computing property price indices based on smoothing the series of mean transaction unit property prices gives more reliable and objective results. Thus, obtained indices are less volatile, less vulnerable to dramatic movements and more immune to values that are highly unlikely from an objective, or expert's point of view. Due to a homogeneous method of their determination, the filtered indices offer the opportunity for comparison in time and space. This is not so obvious in the case of the hedonic indices because they are computed for various cities and time intervals with reference to different models and property baskets. Moreover, some independent studies show that the filtered indices can be computed even for very small local markets, where few transactions are concluded per quarter (КОКОТ 1017).

\section{References}

CEGIELSKI P., 2013, Zastosowanie metod ekonometrycznych do wyceny nieruchomości w podejściu porównawczym (Application of Econometric Methods for Valuating Real Estate in a Comparative Approach), Praca doktorska pod kierunkiem prof. dr hab. Krzysztof Jajugi (Work under the supervion of prof. dr hab Krzysztof Jajugi), Uniwersytet Ekonomiczny we Wrocławiu (Economic University in Wroclaw).

GAMRACKI A., GAMRACKI J., 2009, Szacowanie emisji tlenków azotu (NOx) na podstawie danych eksploatacyjnych rzeczywistego obiektu przemystowego (Estimating the Emission of Nitrogen Oxides (NOx) on the Basis of Operational Data and the Actual Industrial Facility), Pomiary Automatyka Kontrola (Measurements Automation Control) No. 07, Gliwice.

Guo X., Zheng S., GelTner D., Liu H., 2014, A New Approach for Constructing Home Price Indices: The Pseudo Repeat Sales Model and its Application in China, Journal of Housing Economics, Vol. 25.

HILl R., 2011, Hedonic Price Indices for Housing, OECD Statistics Directorate, Working Paper No. 36.

КОКОт S., 2014, Teoretyczne i praktyczne problemy wyznaczania indeksów cen nieruchomości (Theoretical and Practical Problems of Indicating Real Estate Price Indices) Studia i Prace Wydziału Nauk Ekonomicznych i Zarządzania (Studies and Works of Faculty of Economics and Management), No. 36, Metody Ilościowe w Ekonomii (Quantitative Methods in Econometrics), Vol., II, Wydawnictwo Naukowe Uniwersytetu Szczecińskiego (Scientific Publishing of Szczecin University), Szczecin.

КокОт S., 2015A, Jakość danych o cenach transakcyjnych na rynku nieruchomości (Quality of Data on Transaction Prices on the Real Estate Market), Acta Scientarum Polonorum. Administratio Locorum 14 (1), Bydgoszcz, Kraków, Lublin, Olsztyn, Poznań, Siedlce, Szczecin, Warszawa, Wrocław.

КОКОт S., 2015в, Przyczynek do badań nad indeksami cen nieruchomości (Contribution to Studies on Real Estate Price Indices), Wiadomości Statystyczne (Statistical News), No. 4, Warszawa. 
KОКОт S., 2016, Wyznaczanie indeksów cen nieruchomości na podstawie szeregów czasowych median cen jednostkowych wygładzonych filtrem $4253 \mathrm{H}$ (Indicating Indices of Real Estate Prices on the Basis of Time Series of Unit Price Medians Smoothed with 4253H Filter), Nieruchomość w przestrzeni 2 (Real Estate in Space 2), M. Trojanek, Bogucki (eds) Wydawnictwo Naukowe, Poznań.

КОКОт S., 2017, Residential Property Price Indices on Small Property Markets, Real Estate Management and Valuation, Vol. 25, Issue 1.

Konowalczuk J., 2014, The Corporate Real Estate Market in Public Statistics in Poland, Real Estate Management and Valuation, Vol. 22, Issue. 2.

Nicholas T., ScherbinA A., 2013, Real Estate Prices During the Roaring Twenties and the Great Depression, Real Estate Economics, Vol. 41, Issue 2.

TOMCZYK E., WIDŁAK M., 2010, Konstrukcja i własności hedonicznego indeksu cen mieszkań dla Warszawy (Construction and Properties of Hedonic Prices Index of Prices of Flats for Warsaw), Bank i Kredyt (Bank and Credit), No. 41 (1), Narodowy Bank Polski (National Bank of Poland), Warszawa.

TROJANEK R., 2008, Wahania cen na rynku mieszkaniowym (Prices Fluctuations on the Real Estate Market), Published by Akademia Ekonomiczna in Poznań.

TROJANEK R, 2009, Porównanie metody średniej oraz średniej ważonej konstruowania indeksów cen nieruchomości mieszkaniowych (Comparing Average and Weighted Average Methods of Constructing Real Estate Prices Indices), Studia i Materiały Towarzystwa Naukowego Nieruchomości (Journal of the Polish Real Estate Scientific Society), Vol.17, No. 2.

TrojaneK R, 2010, Porównanie metod prostych oraz metody regresji hedonicznej do konstruowania indeksów cen mieszkań (Comparing Simple Methods and Methods of Hedonic Regression for Constructing Housing Price Indices), Studia i Materiały Towarzystwa Naukowego Nieruchomości (Journal of the Polish Real Estate Scientific Society), Vol. 18, No.1.

WIDŁAK M., 2010, Metody wyznaczania hedonicznych indeksów cen jako sposób kontroli zmian jakości dóbr (Methods of Indicating Hedonic Price Indices as a Means of Controlling Changes in the Quality of Goods) Wiadomości Statystyczne (Statistical News), No. 9, Główny Urząd Statystyczny (Central Statistical Office of Poland), Warszawa.

Velleman P. F., 1980, Definition and Comparison of Robust Nonlinear Data Smoothing Algorithms, Journal of the American Statistical Association, Volume 75, Issue 371.

WoOD R., 2005, A Comparison of UK Residential House Price Indices, BIS Paper No. 21.

Wycena nieruchomości (Real Estate Valuation), 2006, J. Hozer (ed.), Katedra Ekonometrii i Statystyki Uniwersytetu Szczecińskiego, (Department of Econometrics and Statistics of Szczecin University) Instytut Analiz Diagnoz i Prognoz Gospodarczych (Institute of Economic Analyses, Diagnoses and Forecasts), Szczecin. 